\title{
Entrepreneurship and the Extensive Margin in Export Growth: A Microeconomic Accounting of Costa Rica's Export Growth during 1997-2007*
}

\author{
Daniel Lederman \\ Andrés Rodríguez-Clare \\ Daniel Yi Xu
}

\begin{abstract}
Successful exporting countries are often seen as successful economies. This paper studies the role of new exporting entrepreneurs - defined as firms that became exporters - in determining export growth in a fast growing and export oriented middle-income country i.e., Costa Rica during 1997-2007. It provides a detailed description of the contribution of export entrepreneurs in the short and long run, and compares the observed patterns with an emerging literature on the role of the "extensive" margin in international trade. On a yearby-year basis, the rate of firm turnover into and out of exporting is high, but exit rates decline rapidly with age (i.e., the number of years the firm has been exporting). On average, about 30 percent of firms in each year tend to exit export activities, and a similar percentage of firms enter. The exiting and entering firms tend to be significantly smaller than incumbent firms in terms of export value (e.g., entrants export about 30 percent less on average than incumbent firms). These findings are consistent with existing evidence for other middle income Latin American countries. However, in the long run new product-firm combinations (i.e., product-firm combinations not present in 1997) account for almost 60 percent of the value of exports in 2007. Surviving new exporters actively adopted new products (for the firm, but not necessarily new for the country) and abandoned weaker existing products they started with, and their export growth rates were very high during a period (1999-2005) when those of incumbent exporting firms were actually negative. JEL codes: F14
\end{abstract}

\footnotetext{
*Daniel Lederman (corresponding author) is a lead economist at the International Trade Department of World Bank. Andrés Rodríguez-Clare is a professor of economics at the Pennsylvania State University and a faculty research associate of NBER. Daniel Yi Xu is an assistant professor of economics at New York University and a faculty research fellow of NBER. The authors gratefully acknowledge financial support from the World Bank's Latin American and Caribbean Regional Studies Program under the proyect on the "Quality of Trade" led by William F. Maloney and from the Costa Rica Competitiveness Project led by José Luis Guasch, Thomas Haven, and José Guilherme Reis. The following colleagues provided useful insights and guidance during preliminary discussions: José Luis Guasch, Porfirio Guevara, Bill Maloney, Martha Denise Pierolo, Roberto Alvarez, and Augusto de la Torre. Javier Cravino and Oana Luca provided stellar research assistance at various stages. Ronald Arce (PROCOMER), Francisco Gamboa (Research Director, PROCOMER), and Ricardo Matarrita (INCAE, formerly with PROCOMER) spent time providing and explaining the PROCOMER data during recent years. Last but not least, we gratefully acknowledge invaluable comments provided by two anonymous referees and Betty Sadoulet.
} 
Successful exporting countries are often seen as successful economies. Most governments use export promotion policies and have established export promotion agencies, regardless of the level of development or institutional capacities (Lederman, Olarreaga and Payton 2010). The World Bank consistently argues that promoting trade and exports in particular is a recipe for promoting firm and national productivity (e.g., Fajnzylber, Guasch, and López 2009). East Asian economies used export targets as part of their development strategies in the 1970s and 1980s (Noland and Pack 2003, Pack 1997). Furthermore, export activities are also seen by policymakers as a means to improve the productivity or other outcomes of small and medium enterprises, and thus export promotion policies are often designed to serve these firms rather than large or multinational corporations (Volpe and Carballo 2008).

In this paper we study the role of new export entrepreneurs in determining export growth. We focus on the case of Costa Rica, a successful middle-income economy, during the period 1997-2007. This article provides a detailed description of the contribution of export entrepreneurs in the short and long run, and compares the observed patterns with an emerging literature on the role of the "extensive" margin in international trade (e.g., Besedes and Prusa 2006, 2010; Eaton et al. 2007; Alvarez and Fuentes 2009; Brenton et al. 2010; Freund and Pierola 2010).

The empirical analysis relies on customs data compiled by the Costa Rican export promotion agency, PROCOMER, which is part of the Ministry of Foreign Trade. The data includes all firms with positive exports during 1997-2007 and provides information on export values by year classified by product categories as well as quantities measured in kilograms and destination markets. Although the information is limited, because it does not 
provide information about domestic sales or other variables that would be needed to calculate standard indicators of firm productivity, it does allow us to decompose export growth and explore the role of firm turnover in and out of exporting activities, as well as the main drivers of export growth across firms of different export sizes (in terms of value).

The main findings are as follows. On a year-by-year basis, the rate of firm turnover into and out of exporting activities is quite high. On average, about 30 percent of incumbent exporting firms in each year tend to exit export activities while a similar percentage of firms are new exporters. The exiting and entering firms tend to be significantly smaller than incumbent firms in terms of export value (e.g., entrants export about 30 percent less on average than incumbent firms). Over 40 percent of firms exit exporting after one year, and the exit rate thereafter hovers around 20 percent. ${ }^{1}$ To put these numbers in an international comparative perspective, Freund and Pierola (2010) report that 34 percent of Peruvian firms that export agricultural and agribusiness products exit after one year. Brenton et al. (2010) report that for middle-income economies only about 51 percent of productdestinations survive past the first year, with the rate of survival stabilizing just below 20 percent in subsequent years.

In the long run, the main driver of export growth in Costa Rica was the introduction of new products by surviving firms. New product-firm combinations (i.e., product-firm combinations not present in 1997) account for almost 60 percent of the value of exports in 2007. Surviving new exporters actively adopt new products (for the firm, but not necessarily new for the country) and abandon weaker existing products they start with.

\footnotetext{
${ }^{1}$ These numbers were calculated by the authors, based on data provided by PROCOMER and cleaned by the authors - see Section II below.
} 
The rest of this paper is organized as follows. Section I briefly compares Costa Rica’s export and growth performance during 1997-2007 with other countries and regions. Section II discusses the PROCOMER data by comparing the series with other data on Costa Rican exports. This section also describes how the firm data was cleaned and discusses key features of the resulting data set, including the lack of significant changes in the composition of exports and exporting firms across broad industrial categories. Section III presents the microeconomic accounting frameworks used to assess the contribution of incumbent and new firms, products and export market destinations, to total export growth in the short run and in the long run. Section IV concludes with a brief summary of the results.

\section{Costa Rica’s Export and Growth Performance in Comparative Perspective, 1997-} 2007

Table 1 shows average growth rates of exports (measured in current U.S. dollars) and Gross Domestic Product per capita (adjusted for Purchasing Power Parity with international prices of 2005) for the period $1997-2007$.

Costa Rica’s average export growth during this period was 9 percent per year. This is a bit higher than the average growth rate for Latin America and the Caribbean region, and clearly superior to the Central America and Caribbean region, but lowers than the average for all the other regions. Within Latin America, Costa Rica’s export growth performance is dominated by Peru and Chile, which achieved export growth rates of $16.4 \%$ and $15.7 \%$, respectively. 
The picture is slightly better when looking at GDP per capita growth rates.

Costa Rica’s economic growth rate of 3.3\% is higher than Peru and Chile, and higher than the average for all regions except Europe and Central Asia and South Asia. This suggests that Costa Rica’s overall economic performance was relatively more impressive than its export growth rate

\section{The PROCOMER Data}

Before conducting a detailed analysis of the microeconomics of export growth, we need to ascertain the quality of the data. Figure 1 compares the value of total Costa Rican merchandise exports in the PROCOMER data with the World Bank's data on total merchandise exports, which come from official government sources,.

The two series are not identical, which is worrisome. However, the over time correlation is very strong, and thus the PROCOMER data does capture the direction if not the exact magnitude of merchandise export growth observed in the macroeconomic data. The divergence between the two series is largest in 1997 and 1998, which converge to a constant gap in 1999. Consequently, the PROCOMER data tend to exaggerate the total export growth rates in 1998 and 1999, but the subsequent growth rates are comparable, as shown in Table 2. Nonetheless, the underlying microeconomic dynamics observed in the PROCOMER data are informative for understanding the sources of total export growth during this time period. 
Unfortunately there are other issues with the PROCOMER data, which would affect the microeconomic analyses. Table 3 lists the steps taken to clean the data and the main features of the resulting data set.

The cleaning focused on issues that are relevant for understanding the microeconomic sources of export growth, including the role of incumbent, new and exiting firms, products and destinations, as well as unit values (the ratio of export value over quantities exported measured in kilograms). Hence we removed duplicate observations of firms-product-destinations, deleted observations where the description of the product was empty, entries where the reported quantity was zero, observations that reported Costa Rica as the destination market, etc. After this phase of the cleaning, the total number of observations of firms-products-year-destinations declined by about 6,000 observations and total export value declined by 0.26 percent. The next step was to remove any remaining duplicate observations that were due to the recording of the same firm, but with spelling mistakes or other errors in the reported name of the firm. This step reduced the total number of firm-product-destination-year observations by about 800 . Finally, given that we are interested in learning about Costa Rican firm dynamics in export activities, we removed the observations corresponding to two big multinational corporations, INTEL and Abbott Labs, whose export experience is better suited for firm case studies. INTEL alone accounted for over 23 percent of the value of exports of Costa Rica during 1997-2007, while Abbot contributed over 3 percent of the total.

Table 4 describes the main features of the resulting data set. Regarding export growth, the resulting data shows a weaker performance than the aggregate export data presented in Figure 1. The year 1998 remains an outlier with a real growth rate of 29 
percent, even after removing the exports from INTEL and Abbot. ${ }^{2}$ This year was also an outlier in the aggregate export data. In the remaining years, the real export growth rates were rather mediocre when compared to the aggregate data, with negative real growth rates during the years of the East Asian financial crisis of 1997-1999, the beginning of the U.S. slowdown in 2000-2001, and the incorporation of China as a full member of the World Trade Organization in 2001. Thereafter the real export growth rates were positive but modest, except in 2006 when it reached 10 percent.

The most striking feature of the data, however, is the low number of firms that reported exports in every year during 1997-2007, which were 554. This is a mere 6.2 percent of the total number of firms that appear in the sample during the eleven years. The number of continuing products, measured either at the 6- or 10-digit product categories, is also small relative to the total number of products exported at any time during this period (27.6 and 15.5 percent, respectively). The difference between these ratios also indicates that the level of aggregation of the product categories affects the accounting of the contribution of the new products. In contrast, the number of export destinations was relatively constant over time, and over 46 percent of destinations were serviced every year. Overall, the cleaned data suggests that the rate of turnover of exporting firms and products is quite high, with very few continuing firms and products, the latter being sensitive to the product nomenclature.

Table 5 provides a standard analysis of the composition of trade. It shows the export shares of broad industrial sectors. If the aforementioned high turnover rates of firms and products were associated with structural change across industries, we should also observe

\footnotetext{
${ }^{2}$ It is noteworthy that both companies began exporting from Costa Rica in 1998.
} 
dramatic changes in the composition of trade. The data in this regard is a bit noisy and needs to be analyzed with caution. The last industry, which is broadly labeled "services", captures over 13 percent of total exports at the beginning of the sample but falls to zero by 2001. Also, the industry labeled "Miscellaneous" experienced a dramatic increase in its share, but it is difficult to interpret these fluctuations in export shares as structural change precisely because these industries are loosely identified. Perhaps more interestingly, between 2001 (when "services” were more appropriately recorded as having a zero share in the merchandise export accounting) and 2007 the most dramatic decline happened in textiles and apparel, an industry that we know faced tough competition from Chinese exports to third markets, including the United States, as a result of its WTO accession and the dismantling of the Multi-Fiber Arrangement that had historically maintained high levels of protection for costly producers in high-income countries (see Ozden and Sharma 2006 and Ozden 2006). ${ }^{3}$ In brief, the changes of the inter-industry structure of Costa Rican exports between 1997 and 2001 seems to be a recording illusion, due to the role of “miscellaneous” and “service” merchandise exports, and after the latter category disappeared in 2001, the only notable structural change is related to the textile and apparel sectors. More importantly, these structural changes are very small when compared to the evidence concerning the rather high rates of firm and product turnover rates during 19972007. Thus, most of the action in terms of firm and product dynamics was within sectors, rather than across broad industrial categories. This observation alone makes the fast growing literature on firm heterogeneity and within industry dynamics (e.g., Melitz 2003)

\footnotetext{
${ }^{3}$ Ozden and Sharma (2006) found that preferential margins on apparel exports to the U.S. from beneficiaries of the Caribbean Basin Initiative declined significantly during 2000-2002 when compared to 1992-2000. Ozden (2006) found that Costa Rican apparel exports to the U.S. declined after 2000, but that average unit values (prices) of apparel exports to the United States rose.
} 
of particular interest to the case of Costa Rica. In this light, the following sections assess the contribution of firm, product and export-destination dynamics to overall export growth.

\section{Accounting for Microeconomic Sources of Export Growth}

What are the main micro sources that drive export dynamics? We borrow the insights from the literature of industry dynamics to view firms' exporting behavior as a process of "creative destruction." A consistent message from the industry dynamics literature, both empirical and theoretical, is that new firms are born small and suffer a high hazard rate of exit. Yet, in the medium to long run, the new firms that manage to survive grow rapidly and take over the incumbents. This in turn forces the inefficient incumbent firms to quit the market.

While a lot of previous studies have looked at the above-described process using data of firm domestic sales, entry, and exit, few have investigated this with data on firm export market dynamics. The related work in this area includes Colombia (Eaton et al., 2007), Chile (Alvarez and Fuentes 2009), and Peru (Freund and Pierola 2010). We believe that looking at trade transactions data brings some empirical advantage compared with previous studies based on industry census data.

First, customs data provides richer information on how new firms expand and prosper over time. They can expand by selling products in more markets, or adopting existing product lines, or creating brand new products. While each of these activities will be reflected in the growth of export sales, they tend to have different implications for competition, resource allocation, and welfare. 
Second, the fact that exporting firms potentially serve multiple markets at different points in time provides rich variation in controlling for firm’s initial heterogeneity and avoids selection bias.

To assess the contribution of microeconomic dynamics related to firm, product and export destinations, we conduct two sets of export-decomposition exercises. The first concerns the contribution of microeconomic dynamics to short-term growth, namely on annual growth rates during 1997-2007. The second explores the contribution of new export entrepreneurs, products and export destinations in the longer run, which is defined as a fiveyear period of export growth (1999-2004).

\section{Short-run decomposition framework}

The export-growth decomposition framework used by Eaton et al. (2007) to study export growth in Colombia is given by equation (1):

$$
\begin{aligned}
& \frac{X_{t}-X_{t-1}}{\frac{1}{2}\left(X_{t-1}+X_{t}\right)}=\left(\frac{\frac{1}{2}\left(X_{t-1}^{C N}+X_{t}^{C N}\right)}{\frac{1}{2}\left(X_{t-1}+X_{t}\right)} * \frac{X_{t}^{C N}-X_{t-1}^{C N}}{\frac{1}{2}\left(X_{t-1}^{C N}+X_{t}^{C N}\right)}\right)+\left(\frac{N E N_{t-1} * \overline{X_{t-1}}}{\frac{1}{2}\left(X_{t-1}+X_{t}\right)}+\frac{X_{t}^{E N}-N E N_{t-1} \overline{X_{t-1}}}{\frac{1}{2}\left(X_{t-1}+X_{t}\right)}\right) \\
& +\left(-\frac{N E X_{t-1} * \overline{X_{t-1}}}{\frac{1}{2}\left(X_{t-1}+X_{t}\right)}-\frac{X_{t-1}^{E X}-N E X_{t-1} \overline{X_{t-1}}}{\frac{1}{2}\left(X_{t-1}+X_{t}\right)}\right)
\end{aligned}
$$

where $X_{t}$ equals total exports in period t; $\bar{X}_{\mathrm{p}-1}$ is the average exports (across firms) in period t-1; CN, EN and EX are indexes for variables corresponding to continuing, entering and exiting firms, respectively (continuing firms are those that exported both in $\mathrm{t}$ and $\mathrm{t}-1$, 
entering firms are those that exported in $t$ but not in $t-1$, and exiting firms are those that exported in $\mathrm{t}-1$ but not in $\mathrm{t}$ ); and $\mathrm{NEN}_{\mathrm{t}}$ and $\mathrm{NEX}_{\mathrm{t}}$ is the number of entering and exiting firms in t, respectively. The denominator in the export growth ratio is the average of exports in $t$ and $t-1$, which Eaton et al. use for convenience so that the growth rates do not depend on the one year. In any case, the results, discussed further below are not significantly affected by this choice of denominator.

In a nutshell, the decomposition exercise separates the contributions to annual export growth of incumbent, entering and exiting firms. The contribution of incumbent firms is simply the product of the share of exports of incumbent firms times their export growth. This contribution appears in the first term inside brackets in equation (1).

The contribution of entering firms has two components, both appearing inside the brackets of the second term on the right-hand side of (1). The first is simply the number of entering firms as a share of average number of total firms in t-1 and t. In (1), this is written as the number of entrants times the average exports per firm in $t-1$. The second component concerns the deviation of the average exports of new firms from the average exports of incumbent firms, the latter being equal to the number of new firms' times the average exports per firm in the previous year. The contribution of exiting firms is analogous to the decomposition of the contribution of entrants.

The results from these decompositions of annual export growth rates are presented in the following section and Table 6a. As discussed below, the annual growth rates are dominated by the contribution of incumbent firms. Thus, we explore the contribution of new and exiting products and export destinations by incumbent firms in Tables 5b and 5c.

\section{Short-run results}


The first column of Table 6a shows the annual growth rate of real exports observed in the cleaned PROCOMER data. The second column shows the share in total exports in the previous year due to incumbent firms, and the third column contains the export growth of these incumbent firms. The evidence clearly shows that incumbent firms dominate export growth from year to year, as over 95 percent of total exports in the previous year were due to firms that remained as exporters in the following year. Consequently the export growth rate of the incumbent firms closely tracks the annual growth of total exports.

Interestingly, the rate of turnover of exporting firms is large. The number of entrants accounts for more than 27 percent of the number of firms in every year - see column 4 . Similarly, the rate of exit is higher than 25 percent every year - see column 6 . Furthermore, the average exports of entrants and departing firms tended to be low relative to the average export value of incumbent firms. This is reflected in the value gap of entrants and departing firms, which was around 30 percent during the period (i.e., entrants were $30 \%$ smaller than incumbents, and similarly for firms that stopped exporting). Thus, incumbent firms' export growth dominates year by year export growth in spite of the rather high turnover rate of exporting firms, because both new and exiting firms export very low values.

The results on firm dynamics for Costa Rica seem high. However, the evidence from Colombia and Chile also suggest that firm turnover in export activities tends to be high. For the case of Colombia, Eaton et al. (2007) report entry rates that average over 45 percent and the average exit rates surpass 43 percent per year during 1996-2005. Alvarez and Fuentes (2009) report comparable rates for Chilean manufacturing exports during 1991-2001 when annual entry rates averaged over 29 percent while exit rates ranged between 8 and 28 percent. Freund and Pierola (2010) also found high entry and exit rates of 
export entrepreneurs in the agricultural and agribusiness sectors in Peru during 1994-2007. ${ }^{4}$ Thus the results for Costa Rica in terms of firm dynamics seems consistent with data from other case studies.

Next, we investigate the growth and decline path of incumbent firms. The customs data provides us with two important dimensions of incumbent firms’ export dynamics: destinations and products. Regarding the role of new export destinations in shaping the growth of exports of incumbent firms, Table 6b shows the results from the decomposition of the annual export growth of incumbent firms into incumbent destinations, new destinations, and exiting destinations. Not surprisingly, incumbent destinations account for most of the observed export growth of incumbent firms, but we do observe non-trivial entry and exit of new destination markets. Table 6c presents the results concerning the contribution of the new and exiting products exported by incumbent firms. The entry and departure rates of products exported by incumbent firms are very high, even higher than the firm and export-destination turnover rates reported in tables 5a and 5b. Also, the value gaps are larger for new and exiting products than for entering and exiting firms or destinations.

In sum, in the short-run, the growth rate of exports by incumbent firms is the main factor behind the aggregate export growth rate, but this occurs with vigorous firm dynamics. These dynamics are characterized by high firm entry and exit from export activities, experimentation by incumbent firms with new markets and especially new products. The introduction of new products and the shedding of existing products by incumbent firms tend to be the largest source of renewal for Costa Rica’s exports.

\footnotetext{
${ }^{4}$ Freund and Pierola (2010) report entries and exits in the annual data ranging from under 100 at the beginning of the period to close to 200 by the end. They also report that the total number of firms in the sectors they investigate peaked at 593 in 2007. Both Freund and Pierola (2010) and Besedes and Prusa (2010) propose theoretical models that rely on ex-post realizations of fixed costs of exporting to explain these high rates of entry and exit.
} 


\section{Firm dynamics and export growth in the long run}

The previously discussed results concern annual export growth rates. Given that incumbent firms dominate aggregate export growth in the short run, but with notably high churning at the firm and firm-product levels, it is worth asking whether new firms, products, or destinations made significant contributions to Costa Rica's total export growth between 1997 and 2007. In the long run we can expect much higher contributions to total exports from firm dynamics. For instance, in the case of Colombia, existing evidence indicates that the contribution of new firms to total export growth (of 7.6 percent) between 1996 and 2005 rose from 10 percent on an annual basis to 26 percent for the whole period. The case of Chilean manufacturing exports is more dramatic: the contribution of entering firms to total export growth during 1991-2001 (which averaged 11.5 percent per year) rises from 23 percent on an annual basis to over 83 percent over the whole period. In the case of Costa Rica, new product-firm combinations (i.e., product-firm combinations not present in 1997) account for almost 60 percent of the value of exports in $2007 .^{5}$ However, what are the firm dynamics behind this high long-run contribution of export entrepreneurship? Is it that new exporters grow faster than incumbent firms when they survive for a few years? If so, is this export growth by new export entrepreneurs associated with changes in products?

To better understand the microeconomic dynamics underpinning the long run result we use the period 1999-2005 and examine the contribution of new exporters relative to incumbents. We start with year 1999 to identify the “new”, exporters. We define any firm that never appears in the customs records before 1999 (i.e. on 1997 and 1998) and enter the

\footnotetext{
${ }^{5}$ This finding is also consistent with an analysis of the contribution of new products and new destinations utilizing SITC 4-digit product level data provided by an anonymous referee: In 2008, ninety three percent of total exports were due to product-destination relationship that existed in 1999.
} 
record on or after 1999 as a "new" firm. This helps to alleviate the concern of the initial status problem since our sample starts in 1997. With a similar rule, we define a firm as an “exiting” exporter if it appears in custom records on or before 2005 and never appears in the customs records after 2005 (i.e. on 2006 and 2007). Incumbent exporters are defined as those that enter before 1999 and survive until 2005. The benefit of these definitions is that the group of incumbent exporters is fixed over the whole period. This allows us to evaluate the contribution of "new" exporters to long-run export growth despite their extremely high year-by-year turnover rate.

Table 7 summarizes the share of Costa Rica's total exports by entrants versus incumbents. It illustrates that the new exporters as a group experienced an increase in exports by almost a factor of ten during the sample period. In contrast, the sales of incumbent exporters declined by $25 \%$ over the same period. This is consistent with earlier empirical findings that older firms grow slower and their growth rate eventually becomes negative (see, for instance, Dunne, Roberts, and Samuelson 1989 on manufacturing plants in the United States). Overall, it is fair to say that new exporters are the main driving force of export growth in this sample period. If we think of "exporting entrepreneurship" as entry of new firms into exporting, we can say that over the medium term export entrepreneurship is the main driver of export growth in Costa Rica. What are these new exporters doing? How are they growing? This is what we explore next.

To further understand the path of new exporter dynamics, we can also look at each cohort of these entrants. We define the year 1999 cohort as the new exporters that appear for the first time in custom records in year 1999. In Table 8 we trace out the annual export sales of surviving 1999 cohort firms and exiting 1999 cohort firms. As shown in Table 8, 
although the majority of the 1999 cohort exited before the end of our sample (only 152 out of 732 remain), the exiting firms as a group account for very little in terms of total export sales of the whole cohort. As a result, total exports of this cohort were dominated by surviving firms. The results of Table 8 are consistent with the view that although new exporters enter small and have a high failure rate, the surviving ones tend to catch up with incumbents quickly.

A natural question here is whether the new product margin is an important channel for growth among surviving new exporters. To answer this question, we separate new exporters" products into two categories. We define "initial products" as the 6-digit products that the new exporters sell in the first year of their export market participation. We further define "added products" as those 6-digit products that are added in their later years of exporting. In Table 9a, we report the sales coming from “initial products” and “added products” for the surviving exporters within the 1999 and 2000 cohorts. Both cohorts exhibit a similar pattern: the new product margin and the initial product margin are equally important in contributing to new exporters' sales growth in the long run. The "added products” category explains close to $40 \%$ of new exporters' growth after 5 years, while the within "initial product" category growth is also very strong over the similar time span and explains 60\%. In contrast, in Table 9b, we report the value of “continuing products” and “added products” of incumbent firms which survive until year 2005. For this group of firms, the “continuing products” are 6-digit products they’ve already exported before 1999. Although this group of firms as a whole declines over time, their "added products" still grows quite substantially from 1999-2005. However, compared with the new exporters of 1999 and 2000, the growth rate of “added products” from incumbent firms is lower. 
Table 9c documents how new exporters drop their initial products and how the remaining initial products grow. We again focus on the 1999 cohort. The evidence suggests that the creative destruction process on the product margin within exporters also has a strong selection effect. New exporters keep only the strongest products that they start with and drop the weaker products along the way. Table 9d reports how incumbent exporters drop their continuing products and how the surviving products grow. Similar to new exporters, incumbent exporters also drop their weaker products over the years. However, their surviving products also decline gradually, while the surviving initial products of new exporters grow strongly. This explains a large fraction of the difference in export growth between new and incumbent exporters

Overall, Tables 6-8 provide a coherent picture of Costa Rica’s export growth from 1999 - 2005. We find that the surviving new exporters are the major contributing force to aggregate export growth. Meanwhile, they actively adopt more products and abandon weaker existing products they start with. So in this sense, the survival of new exporters itself is not random: it is partially determined by a firm's active experimentation with their export product lines.

\section{Conclusion}

Costa Rica’s export growth was not stellar when compared to other countries, and even less so without the contributions of two large multinational corporations. Inter-sectoral adjustments across broad industries were negligible, both in terms of export-value shares and in terms of the number of exporting firms as a share of the total number of exporting firms. Hence, most of the action seems to be associated to within-industry dynamics. 
In the short run, by far the major contribution to export growth came from incumbents exporting more of the same products to the same markets, but there are high rates of turnover in firms, products and destinations that become very important in the long run. Almost 60 percent of export growth was due to incumbent firms exporting products that were not originally exported in 1997. Most of this number is due to surviving new exporters who actively add new products and drop weaker ones.

Overall, one way to interpret our findings is that the country's export performance was primarily limited by the inability of firms to survive the test of exporting. In contrast, it is difficult to interpret our findings as providing support for one of the key suspected obstacles to export growth, namely the inability of small firms to enter exporting activities or to grow their exports. In fact, new exporting firms experienced the fastest growth in their export values, so that over the long run they contribute almost as much to overall export growth as incumbents. 


\section{Appendix}

Table A1. Broad Industrial HS Classification Used in Table 5.

\begin{tabular}{|l|l|}
\hline 1 & Animal and Animal Products \\
\hline 2 & Vegetable Products \\
\hline 3 & Food stuffs \\
\hline 4 & Mineral Products \\
\hline 5 & Chemicals and Allied Industries \\
\hline 6 & Plastics / Rubbers \\
\hline 7 & Raw Hides, Skins, Leather, and Furs \\
\hline 8 & Wood and Wood Products \\
\hline 9 & Textiles / Apparel \\
\hline 10 & Footwear / Headgear \\
\hline 11 & Stone / Glass \\
\hline 12 & Metals \\
\hline 13 & Machinery / Electrical \\
\hline 14 & Transportation \\
\hline 15 & Miscellaneous \\
\hline 16 & Service \\
\hline
\end{tabular}




\section{References}

Alvarez, Roberto, and Rodrigo Fuentes. 2009. “The Quality of Trade: Unit Value Dynamics.” Mimeo. Central Bank of Chile and Department of Economics, Catholic University of Chile, Santiago, Chile.

Besedes, T., Prusa, T.J. 2010. “The Role of the Extensive and Intensive Margins and Export Growth.” Journal of Development Economics, forthcoming,

Besedes, Tibor, and Thomas Prusa. 2006. “Ins, Outs and the Duration of Trade.” Canadian Journal of Economics 104(1): 635-54.

Brenton, Paul, Christian Saborowski, and Erik Von Uexkull. 2010. "What Explains the Low Survival Rate of Developing Country Export Flows?” The World Bank Economic Review, forthcoming

Dunne, Timothy, Mark J. Roberts, and Larry Samuelson. 1989. “The Growth and Failure of U.S. Manufacturing Plants.” The Quarterly Journal of Economics 104(4): 671-98.

Eaton, Jonathan, Eslava, Marcela, Kugler, Maurice and James Tybout. 2007. “Export Dynamics in Colombia: Firm-Level Evidence.” NBER Working Paper 13351, National Bureau of Economic Research, Inc., Cambridge, MA. 
Fajnzylber, Pablo, José L. Guasch, and J. Humberto López, editors. 2009. Does the Investment Climate Matter? Microeconomic Foundations of Growth in Latin America. World Bank: Washington, DC.

Freund, Caroline, and Martha Denisse Pierola. 2008. “Export Entrepreneurs: Evidence from Peru.” World Bank Policy Research Working Paper 5407, Washington, DC.

Lederman, Daniel, Marcelo Olarreaga, and Lucy Payton. 2010. “Export Promotion Agencies: Do They Work?” Journal of Development Economics 91: 257-65.

Melitz, Marc. 2003. “The Impact of Trade on Intra-Industry Reallocations and Aggregate Industry Productivity.” Econometrica 71(6): 1695-1725.

Noland, Marcus, and Howard Pack. 2003. Industrial Policy in an Era of Globalization: Lessons from Asia. Institute for International Economics: Washington, DC.

Ozden, Caglar. 2006. “Caribbean Basin Initiative Beneficiary Countries and the Apparel Sector: Same Preferences, Different Responses.” Mimeo, Development Research Group, The World Bank, Washington, DC.

Ozden, Caglar, and Gunjan Sharma. 2006. "Price Effects of Preferential Market Access: Caribbean Basin Initiative and the Apparel Sector.” World Bank Economic Review 20(2): 241-260. 
Pack, Howard. 1997. “The Role of Exports in Asian Economic Development and Lessons from Latin America.” In Pathways to Growth, edited by N. Birdsall and F. Jaspersen. Baltimore: Johns Hopkins University Press.

Volpe Martinicus, Christian, and Jerónimo Carballo. 2008. “Beyond Average Effects: The Distributional Impacts of Export Promotion Programs in Developing Countries.” Mimeo. Inter-American Development Bank, Washington, DC. 
Figure 1. Costa Rica: Merchandise Exports versus PROCOMER Data, 1997-2007

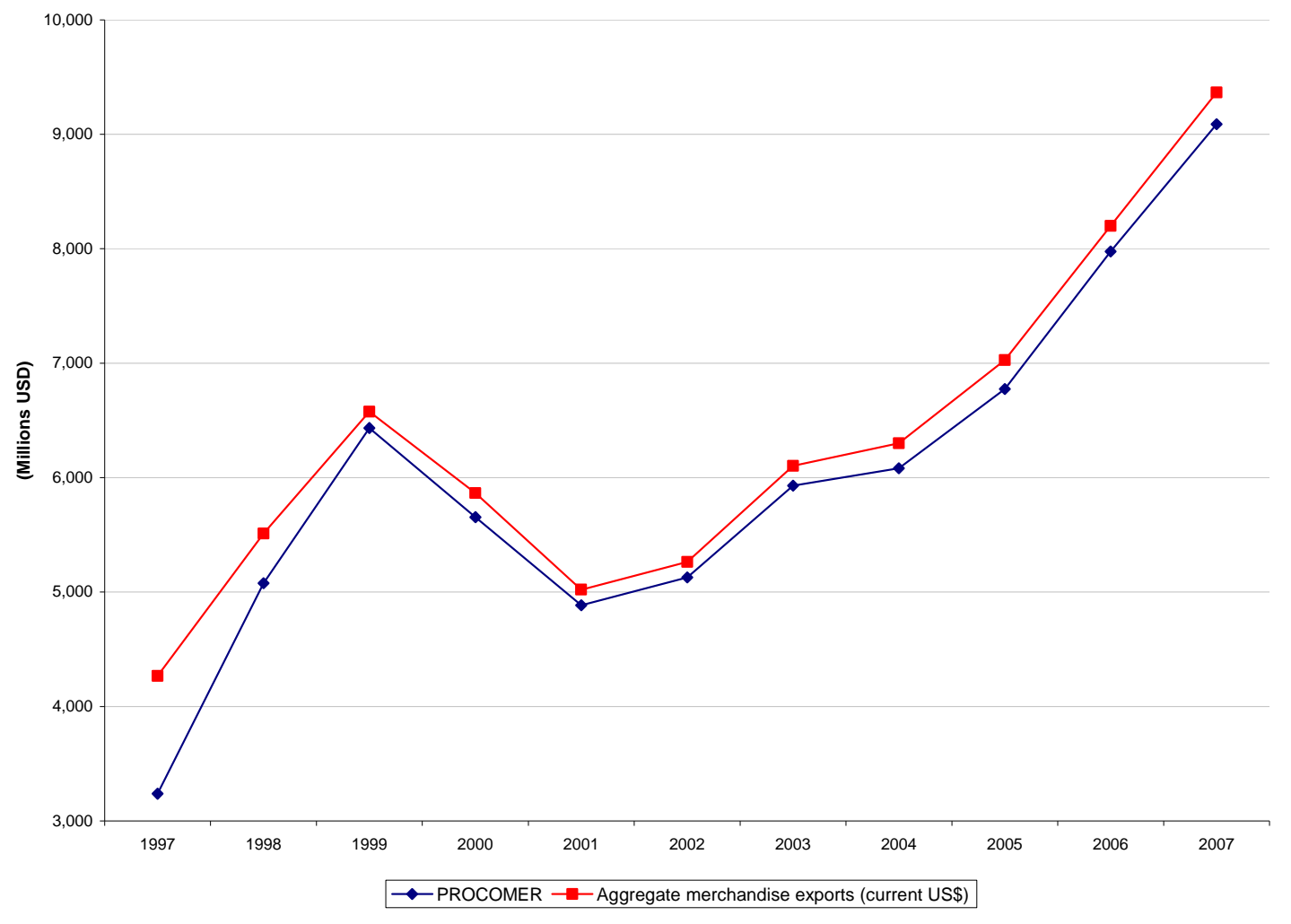

Source: Data are from PROCOMER and World Bank, and both series are expressed in current U.S. dollars. 
Table 1. Annual Merchandise Export and GDP per Capita Growth Rates, 1997-2007

\begin{tabular}{|c|c|c|c|c|}
\hline \multirow[t]{2}{*}{ Country/Groups } & \multicolumn{2}{|c|}{ Exports } & \multicolumn{2}{|c|}{ GDP per Capital (PPP) } \\
\hline & Mean & Median & Mean & Median \\
\hline Costa Rica (1) & 0.090 & 0.129 & 0.033 & 0.042 \\
\hline \multicolumn{5}{|c|}{ Export Over Achievers } \\
\hline Peru (2) & 0.164 & 0.160 & 0.028 & 0.033 \\
\hline Chile (2) & 0.157 & 0.147 & 0.026 & 0.030 \\
\hline China (3) & 0.215 & 0.215 & 0.088 & 0.088 \\
\hline Cambodia (3) & 0.200 & 0.173 & 0.073 & 0.074 \\
\hline Azerbaijan (4) & 0.317 & 0.361 & 0.140 & 0.100 \\
\hline Albania (4) & 0.253 & 0.266 & 0.065 & 0.055 \\
\hline Libya (5) & 0.210 & 0.230 & 0.016 & 0.026 \\
\hline Lebanon (5) & 0.198 & 0.168 & 0.013 & 0.012 \\
\hline Buthan (6) & 0.199 & 0.127 & 0.061 & 0.045 \\
\hline India (6) & 0.158 & 0.193 & 0.055 & 0.062 \\
\hline Chad(7) & 0.520 & 0.058 & 0.046 & 0.039 \\
\hline Sierra Leone (7) & 0.447 & 0.480 & 0.043 & 0.039 \\
\hline Slovak Republic (8) & 0.207 & 0.154 & 0.048 & 0.041 \\
\hline Czech Republic (8) & 0.190 & 0.156 & 0.035 & 0.037 \\
\hline Equatorial Guinea (9) & 0.374 & 0.422 & 0.190 & 0.143 \\
\hline Trinidad and Tobago (9) & 0.215 & 0.236 & 0.076 & 0.074 \\
\hline Kazakhstan (10) & 0.240 & 0.243 & 0.080 & 0.089 \\
\hline Lybia (10) & 0.210 & 0.230 & 0.016 & 0.026 \\
\hline Sudan (11) & 0.340 & 0.291 & 0.045 & 0.040 \\
\hline Azerbaijan (11) & 0.317 & 0.361 & 0.140 & 0.100 \\
\hline Chad (12) & 0.520 & 0.058 & 0.046 & 0.039 \\
\hline Sierra Leone (12) & 0.447 & 0.480 & 0.043 & 0.039 \\
\hline \multicolumn{5}{|c|}{ Other Comparator Countries } \\
\hline Singapore & 0.100 & 0.129 & 0.034 & 0.040 \\
\hline Ireland & 0.087 & 0.078 & 0.047 & 0.037 \\
\hline Hong Kong & 0.067 & 0.090 & 0.032 & 0.040 \\
\hline \multicolumn{5}{|c|}{ Regional and Income Groups } \\
\hline Latin America and Caribbean & 0.084 & 0.083 & 0.020 & 0.019 \\
\hline Central America and Caribbean (1) & 0.055 & 0.051 & 0.022 & 0.023 \\
\hline Latin America (2) & 0.114 & 0.123 & 0.017 & 0.014 \\
\hline East Asia and Pacific (3) & 0.097 & 0.088 & 0.026 & 0.020 \\
\hline Europe and Central Asia (4) & 0.168 & 0.171 & 0.062 & 0.060 \\
\hline Middle East and North Africa (5) & 0.163 & 0.162 & 0.023 & 0.026 \\
\hline South Asia (6) & 0.126 & 0.104 & 0.042 & 0.042 \\
\hline Sub-Saharan Africa (7) & 0.121 & 0.094 & 0.017 & 0.016 \\
\hline High income OECD members (8) & 0.097 & 0.087 & 0.026 & 0.023 \\
\hline High income non OECD economies (9) & 0.112 & 0.095 & 0.035 & 0.025 \\
\hline Upper-middle income economies (10) & 0.105 & 0.093 & 0.034 & 0.030 \\
\hline Lower-middle income economies (11) & 0.135 & 0.114 & 0.035 & 0.026 \\
\hline Low income economies (12) & 0.119 & 0.094 & 0.017 & 0.018 \\
\hline
\end{tabular}

Note: This table presents mean and median annual growth rates of merchandise exports (current US\$) and GDP per capita PPP (constant 2005 international \$) for each of the described groups. The regional and income country classifications come from the World Bank (as of July 2008). Each country's group is indicated inside parentheses. Highlighted cells indicate cases where the corresponding mean or median growth rate was below Costa Rica's. All data are from the World Bank's World Development Indicators. 
Table 2. Costa Rica: Merchandise Export Growth Rate

\begin{tabular}{|ccc|}
\hline & $\begin{array}{c}\text { Procome Export } \\
\text { Growth (\%) }\end{array}$ & $\begin{array}{c}\text { Export } \\
\text { Growth } \\
\text { WDI }\end{array}$ \\
\hline 1998 & 56.8 & 29.1 \\
1999 & 26.7 & 19.3 \\
2000 & -12.1 & -10.8 \\
2001 & -13.6 & -14.4 \\
2002 & 5.0 & 4.8 \\
2003 & 15.6 & 15.9 \\
2004 & 2.5 & 3.3 \\
2005 & 11.4 & 11.5 \\
2006 & 17.8 & 16.7 \\
2007 & 13.9 & 14.2 \\
\hline
\end{tabular}

Source: Data are from PROCOMER and

World Bank, and both series are expressed in current U.S. dollars. 
Table 3. Cleaning the PROCOMER Data

\begin{tabular}{|c|c|c|c|}
\hline Step & $\begin{array}{c}\text { \# of } \\
\text { observations }\end{array}$ & $\begin{array}{c}\text { Total real export } \\
\text { value (1997 U.S.\$) }\end{array}$ & $\begin{array}{c}\text { Share of } \\
\text { initial } \\
\text { value (\%) }\end{array}$ \\
\hline Raw data & 296,238 & $59,219,688,885$ & 100 \\
\hline (-) Duplicate entries & 10 & 174,453 & 0.00 \\
\hline (-) Entries with desc $=" " \prime$ & 56 & $3,584,951$ & 0.01 \\
\hline (-) Entries with quantity 0 & 4,739 & $3,638,070$ & 0.01 \\
\hline (-) country: Costa Rica & 217 & $2,144,049$ & 0.00 \\
\hline (-) country: Alta Mar & 4 & 44,239 & 0.00 \\
\hline (-) country: Generico & 189 & $4,821,894$ & 0.01 \\
\hline (-) country: Zonas Francas de Exportacion & 678 & $148,249,409$ & 0.25 \\
\hline Subtotal & 290,345 & $59,057,031,820$ & 99.73 \\
\hline $\begin{array}{l}\text { Cleaning firm-product-year-country } \\
\text { observations } \\
\text { (consolidation of observations with similar } \\
\text { firm names) }\end{array}$ & 289,549 & $59,057,031,820$ & 99.73 \\
\hline (-) Abbott entries (product-destination-years) & 1,157 & $1,816,626,930$ & 3.07 \\
\hline (-) Intel entries (product-destination-years) & 3,277 & $13,689,799,703$ & 23.12 \\
\hline Cleaned data & 285,115 & $43,550,605,188$ & 73.54 \\
\hline
\end{tabular}

Source: Authors' calculations based on data from PROCOMER. 
Table 4. Summary of the Cleaned PROCOMER Data: Real Export Growth, Firms, Products, and Destinations

\begin{tabular}{|c|c|c|c|c|c|c|}
\hline Year & $\begin{array}{c}\text { Total exports } \\
(\mathbf{1 9 9 7} \text { USD) }\end{array}$ & $\begin{array}{c}\text { Growth } \\
\mathbf{( \% )}\end{array}$ & Firms & $\begin{array}{c}\text { HS6 } \\
\text { products }\end{array}$ & $\begin{array}{c}\text { HS10 } \\
\text { products }\end{array}$ & Destinations \\
\hline 1997 & $3,217,752,622$ & - & 2,200 & 2,454 & 3,283 & 121 \\
\hline 1998 & $4,157,732,964$ & 29 & 2,328 & 2,629 & 3,513 & 129 \\
\hline 1999 & $3,911,376,028$ & -6 & 2,432 & 2,599 & 3,505 & 116 \\
\hline 2000 & $3,695,897,353$ & -6 & 2,392 & 2,594 & 3,557 & 121 \\
\hline 2001 & $3,573,232,631$ & -3 & 2,493 & 2,626 & 3,641 & 127 \\
\hline 2002 & $3,827,746,595$ & 7 & 2,531 & 2,592 & 3,707 & 129 \\
\hline 2003 & $3,860,064,635$ & 1 & 2,670 & 2,736 & 3,869 & 133 \\
\hline 2004 & $4,055,665,596$ & 5 & 2,760 & 2,774 & 3,915 & 134 \\
\hline 2005 & $4,083,061,065$ & 1 & 2,863 & 2,800 & 3,933 & 138 \\
\hline 2006 & $4,507,923,206$ & 10 & 2,937 & 2,833 & 4,087 & 136 \\
\hline 2007 & $4,660,152,494$ & 3 & 2,973 & 2,878 & 4,293 & 151 \\
\hline $1997-2007$ (total) & & 8,865 & 4,568 & 7,941 & 189 \\
\hline $1997-2007$ (continuing) & & 554 & 1,262 & 1,232 & 88 \\
\hline Continuing/Unique (\%) & 6.2 & 27.6 & 15.5 & 46.6 \\
\hline
\end{tabular}

Source: Authors' calculations based on data from PROCOMER and World Bank. Export growth is expressed in constant U.S. dollars of 1997, using the U.S. Producer Price Index as deflator. 
Table 5. Broad Inter-Sectoral Changes are Absent

\begin{tabular}{|c|c|c|c|c|c|c|c|c|c|c|c|}
\hline \multicolumn{12}{|c|}{ A. Sectoral Shares in Total Exports (\%) } \\
\hline Ind & 1997 & 1998 & 1999 & 2000 & 2001 & 2002 & 2003 & 2004 & 2005 & 2006 & 2007 \\
\hline 1 & 10.3 & 8.6 & 4.4 & 4.2 & 4.4 & 4.1 & 4.0 & 3.4 & 3.6 & 3.0 & 3.0 \\
\hline 2 & 33.1 & 29.9 & 31.0 & 27.0 & 26.9 & 25.5 & 27.9 & 27.0 & 26.1 & 26.7 & 27.9 \\
\hline 3 & 8.5 & 8.2 & 8.7 & 9.0 & 9.4 & 10.2 & 10.1 & 11.2 & 11.0 & 11.6 & 13.5 \\
\hline 4 & 0.8 & 0.7 & 0.8 & 1.5 & 1.4 & 1.6 & 0.9 & 0.3 & 1.0 & 0.9 & 1.0 \\
\hline 5 & 5.1 & 5.0 & 5.8 & 6.6 & 7.7 & 7.9 & 8.5 & 8.5 & 8.2 & 7.8 & 8.1 \\
\hline 6 & 3.7 & 3.2 & 4.0 & 4.5 & 4.9 & 5.2 & 5.5 & 6.0 & 6.6 & 6.5 & 6.0 \\
\hline 7 & 1.1 & 1.4 & 1.5 & 1.2 & 1.2 & 1.0 & 1.2 & 1.8 & 1.7 & 1.4 & 1.1 \\
\hline 8 & 3.0 & 2.7 & 3.0 & 2.9 & 3.0 & 2.9 & 2.6 & 3.3 & 3.3 & 3.4 & 3.7 \\
\hline 9 & 6.0 & 16.7 & 18.0 & 19.1 & 18.0 & 17.4 & 13.9 & 11.7 & 10.4 & 8.1 & 6.8 \\
\hline 10 & 0.5 & 0.5 & 0.4 & 0.2 & 0.1 & 0.0 & 0.0 & 0.0 & 0.0 & 0.0 & 0.0 \\
\hline 11 & 2.0 & 2.5 & 2.6 & 2.2 & 2.5 & 2.7 & 2.3 & 2.1 & 2.4 & 2.9 & 2.5 \\
\hline 12 & 2.8 & 2.6 & 2.8 & 3.0 & 3.0 & 3.0 & 3.1 & 3.7 & 4.2 & 4.9 & 5.7 \\
\hline 13 & 8.0 & 10.8 & 9.6 & 12.4 & 11.5 & 12.6 & 13.1 & 14.2 & 13.6 & 14.6 & 11.4 \\
\hline 14 & 0.2 & 0.3 & 0.4 & 0.8 & 0.9 & 0.5 & 0.7 & 0.4 & 0.5 & 0.5 & 0.7 \\
\hline 15 & 1.6 & 3.7 & 4.0 & 4.1 & 5.1 & 5.4 & 6.0 & 6.5 & 7.3 & 7.6 & 8.8 \\
\hline 16 & 13.2 & 3.1 & 2.9 & 1.1 & 0.0 & 0.0 & 0.0 & 0.0 & 0.0 & 0.0 & 0.0 \\
\hline \multicolumn{12}{|c|}{ B. Sectoral Share in Total Firms (\%) } \\
\hline & 1997 & 1998 & 1999 & 2000 & 2001 & 2002 & 2003 & 2004 & 2005 & 2006 & 2007 \\
\hline 1 & 6.9 & 6.9 & 6.5 & 5.6 & 6.3 & 6.0 & 6.1 & 5.5 & 5.0 & 4.9 & 4.4 \\
\hline 2 & 28.5 & 27.1 & 27.4 & 29.8 & 30.7 & 29.1 & 28.2 & 27.6 & 26.1 & 28.1 & 28.8 \\
\hline 3 & 9.2 & 9.8 & 10.1 & 10.6 & 10.4 & 9.8 & 9.8 & 10.5 & 10.5 & 10.7 & 10.3 \\
\hline 4 & 3.6 & 4.7 & 4.1 & 4.0 & 3.7 & 3.7 & 3.6 & 3.8 & 3.7 & 3.8 & 3.6 \\
\hline 5 & 14.1 & 15.0 & 15.2 & 16.0 & 16.3 & 16.8 & 16.6 & 16.7 & 16.6 & 16.7 & 16.4 \\
\hline 6 & 15.2 & 18.1 & 18.5 & 19.1 & 18.7 & 18.4 & 19.4 & 20.2 & 21.2 & 21.6 & 21.6 \\
\hline 7 & 3.0 & 3.4 & 3.2 & 3.4 & 3.6 & 3.2 & 3.9 & 4.1 & 3.9 & 3.6 & 3.5 \\
\hline 8 & 18.8 & 19.7 & 20.1 & 19.9 & 20.8 & 20.4 & 21.1 & 21.2 & 22.2 & 20.4 & 20.8 \\
\hline 9 & 11.1 & 11.4 & 12.3 & 12.3 & 11.4 & 9.9 & 10.0 & 10.6 & 10.3 & 9.1 & 9.5 \\
\hline 10 & 2.9 & 3.0 & 2.7 & 2.9 & 2.5 & 3.0 & 3.5 & 3.4 & 3.1 & 3.2 & 3.5 \\
\hline 11 & 6.2 & 6.8 & 6.5 & 5.8 & 5.9 & 6.3 & 7.0 & 6.7 & 7.4 & 7.3 & 6.6 \\
\hline 12 & 15.1 & 16.4 & 16.4 & 15.7 & 16.6 & 16.7 & 16.9 & 17.8 & 18.1 & 19.1 & 18.2 \\
\hline 13 & 22.4 & 25.3 & 26.1 & 26.2 & 25.8 & 26.6 & 26.9 & 26.7 & 28.2 & 28.4 & 27.8 \\
\hline 14 & 3.6 & 5.2 & 4.2 & 4.6 & 4.9 & 5.1 & 4.2 & 5.0 & 4.8 & 5.3 & 5.4 \\
\hline 15 & 14.5 & 17.1 & 17.6 & 18.3 & 18.6 & 20.0 & 18.4 & 19.0 & 20.8 & 20.0 & 18.8 \\
\hline 16 & 9.5 & 5.8 & 2.5 & 2.3 & 0.6 & 0.2 & 0.1 & 0.1 & 0.0 & 0.0 & 0.1 \\
\hline
\end{tabular}

Source: Authors' calculations based on data from PROCOMER. Ind = industry. See industry classification in the Appendix. 
Table 6a. The Contribution of Firm Turnover in the Short Run

\begin{tabular}{|l|ccccccc|}
\hline & $\begin{array}{c}\text { Export } \\
\text { growth } \\
\text { (\%) }\end{array}$ & $\begin{array}{c}\text { Share } \\
\text { cont. firms } \\
(\mathbf{\%})\end{array}$ & $\begin{array}{c}\text { Growth } \\
\text { cont. firms } \\
\text { (\%) }\end{array}$ & $\begin{array}{c}\text { Entry } \\
\text { (\%) }\end{array}$ & $\begin{array}{c}\text { Entry value } \\
\text { gap (\%) }\end{array}$ & Exit (\%) & $\begin{array}{c}\text { Exit value } \\
\text { gap (\%) }\end{array}$ \\
\hline 1998 & 25 & 97 & $\mathbf{2 6}$ & 30 & -27 & -25 & 23 \\
1999 & -6 & 95 & -7 & 35 & -30 & -31 & 26 \\
2000 & -6 & 96 & -4 & 30 & -28 & -32 & 27 \\
2001 & -3 & 97 & $-\mathbf{4}$ & 34 & -31 & -30 & 28 \\
2002 & 7 & 98 & $\mathbf{7}$ & 30 & -28 & -29 & 27 \\
2003 & 1 & 98 & $\mathbf{1}$ & 34 & -32 & -29 & 26 \\
2004 & 5 & 98 & $\mathbf{7}$ & 32 & -30 & -28 & 25 \\
2005 & 1 & 99 & $\mathbf{1}$ & 33 & -31 & -29 & 28 \\
2006 & 10 & 98 & $\mathbf{1 1}$ & 29 & -27 & -27 & 24 \\
2007 & 3 & 99 & $\mathbf{3}$ & 27 & -26 & -25 & 24 \\
\hline
\end{tabular}

Source: Authors' calculations based on data from PROCOMER. Cont.= continuing or incumbent firms.

Table 6b. The Contribution of Destination Turnover among Incumbent Firms in the Short Run

\begin{tabular}{|c|ccccccc|}
\hline & $\begin{array}{c}\text { Growth } \\
\text { cont. } \\
\text { firms } \\
\mathbf{( \% )}\end{array}$ & $\begin{array}{c}\text { Share } \\
\text { cont. } \\
\text { firm_dest } \\
\mathbf{( \% )}\end{array}$ & $\begin{array}{c}\text { Growth } \\
\text { cont. firm- } \\
\text { dest (\%) }\end{array}$ & $\begin{array}{c}\text { Entry } \\
\mathbf{( \% )}\end{array}$ & $\begin{array}{c}\text { Entry value } \\
\text { gap (\%) }\end{array}$ & $\begin{array}{c}\text { Exit (\%) } \\
\text { Exit value } \\
\text { gap (\%) }\end{array}$ \\
\hline 1998 & $\mathbf{2 6}$ & 96 & 25 & 28 & -23 & -23 & 20 \\
1999 & -7 & 95 & -5 & 27 & -24 & -30 & 24 \\
2000 & $-\mathbf{4}$ & 97 & -4 & 28 & -26 & -26 & 23 \\
2001 & $\mathbf{- 5}$ & 97 & -4 & 26 & -23 & -27 & 24 \\
2002 & $\mathbf{7}$ & 96 & 8 & 25 & -22 & -26 & 22 \\
2003 & $\mathbf{1}$ & 98 & 1 & 27 & -25 & -24 & 22 \\
2004 & $\mathbf{7}$ & 98 & 7 & 26 & -24 & -24 & 22 \\
2005 & $\mathbf{1}$ & 97 & -1 & 28 & -25 & -25 & 23 \\
2006 & $\mathbf{1 1}$ & 98 & 10 & 26 & -23 & -24 & 22 \\
2007 & $\mathbf{3}$ & 97 & 4 & 28 & -25 & -24 & 20 \\
\hline
\end{tabular}

Source: Authors' calculations based on data from PROCOMER.

Table 6c. The Contribution of Product Turnover among Incumbent Firms in the Short Run

\begin{tabular}{|c|ccccccc|}
\hline & $\begin{array}{c}\text { Growth } \\
\text { cont. } \\
\text { firms } \\
\text { (\%) }\end{array}$ & $\begin{array}{c}\text { Share } \\
\text { cont. } \\
\text { firm_prod } \\
\mathbf{( \% )}\end{array}$ & $\begin{array}{c}\text { Growth } \\
\text { cont. } \\
\text { firm_prod } \\
\mathbf{( \% )}\end{array}$ & $\begin{array}{c}\text { Entry } \\
\text { (\%) }\end{array}$ & $\begin{array}{c}\text { Entry value } \\
\text { gap (\%) }\end{array}$ & Exit (\%) & $\begin{array}{c}\text { Exit value } \\
\text { gap (\%) }\end{array}$ \\
\hline 1998 & $\mathbf{2 6}$ & 94 & 30 & 50 & -45 & -41 & 34 \\
1999 & -7 & 94 & -1 & 52 & -49 & -51 & 42 \\
2000 & $-\mathbf{4}$ & 97 & -4 & 54 & -51 & -49 & 46 \\
2001 & -5 & 96 & -7 & 53 & -48 & -49 & 46 \\
2002 & $\mathbf{7}$ & 96 & 6 & 46 & -41 & -45 & 41 \\
2003 & $\mathbf{1}$ & 96 & 5 & 53 & -50 & -46 & 40 \\
2004 & $\mathbf{7}$ & 96 & 6 & 48 & -44 & -46 & 43 \\
2005 & $\mathbf{1}$ & 98 & 0 & 50 & -48 & -46 & 45 \\
2006 & $\mathbf{1 1}$ & 98 & 10 & 48 & -46 & -44 & 42 \\
2007 & $\mathbf{3}$ & 92 & 2 & 51 & -43 & -48 & 41 \\
\hline
\end{tabular}

Source: Authors' calculations based on data from PROCOMER. 
Table 7. The Contribution of New vs. Incumbent Exporters in the Long Run

\begin{tabular}{|c|cccc|}
\hline & \multicolumn{2}{|c}{ New } & \multicolumn{2}{c|}{ Incumbent } \\
& Sales Share (\%) & Number & Sales Share (\%) & Number \\
\hline 1999 & 5 & 732 & 95 & 823 \\
2000 & 13 & 942 & 87 & 817 \\
2001 & 18 & 1,221 & 82 & 821 \\
2002 & 25 & 1,391 & 75 & 818 \\
2003 & 32 & 1,616 & 68 & 834 \\
2004 & 36 & 1,791 & 64 & 846 \\
2005 & 39 & 1,885 & 61 & 922 \\
\hline
\end{tabular}


Table 8. Total Sales of 1999 New Exporters: Survivors vs. Exits (millions of US \$)

\begin{tabular}{|c|ccc|}
\hline & $\begin{array}{c}\text { Survivors } \\
\text { from 1999-2005 }\end{array}$ & $\begin{array}{c}\text { Exit } \\
\text { at Year } \mathbf{x}\end{array}$ & $\begin{array}{c}\text { Survive Year } \mathbf{x} \\
\text { But Exit Later }\end{array}$ \\
\hline 1999 & 157 & 15.0 & 36.1 \\
2000 & 332 & 9.46 & 50.4 \\
2001 & 270 & 6.85 & 45.0 \\
2002 & 337 & 1.63 & 22.7 \\
2003 & 422 & 12.1 & 4.96 \\
2004 & 581 & 3.05 & \\
2005 & 641 & & \\
\hline
\end{tabular}


Table 9a. Total Sales of 1999/2000 New Exporters: Initial Products vs. Added Products (millions of US \$)

\begin{tabular}{|c|cccc|}
\hline & \multicolumn{2}{|c}{ Cohort 1999 } & \multicolumn{2}{c|}{ Cohort 2000 } \\
& Initial Products & Added Products & Initial Products & Added Products \\
\hline 1999 & 157 & & & \\
2000 & 324 & 7.87 & 79 & \\
2001 & 241 & 29.0 & 188 & 12.8 \\
2002 & 298 & 39.7 & 200 & 41.2 \\
2003 & 358 & 63.3 & 229 & 76.3 \\
2004 & 442 & 140.0 & 245 & 82.1 \\
2005 & 406 & 235.0 & 209 & 102.0 \\
\hline
\end{tabular}

Table 9b. Total Sales of Incumbent Exporters: Continuing Products vs. Added Products (millions of US \$)

\begin{tabular}{|c|cc|}
\hline & $\begin{array}{c}\text { Incumbent Exporters - 2005 } \\
\text { Continuing } \\
\text { Products }\end{array}$ & Added Products \\
\hline 1999 & 2510 & 58.9 \\
2000 & 2480 & 147 \\
2001 & 2260 & 222 \\
2002 & 2250 & 363 \\
2003 & 2160 & 497 \\
2004 & 2260 & 677 \\
2005 & 2160 & 695 \\
\hline
\end{tabular}

Table 9c. Total Sales of 1999 Cohort Surviving Exporters: Initial Products Dropped (millions of US \$)

\begin{tabular}{|cccc|}
\hline & $\begin{array}{c}\text { Initial Products } \\
\text { Surviving 99-05 }\end{array}$ & $\begin{array}{c}\text { Initial Products } \\
\text { Dropped Before 05 }\end{array}$ & Total \\
\hline 1999 & 132 & 25.5 & 157 \\
2000 & 284 & 39.6 & 324 \\
2001 & 217 & 23.6 & 241 \\
2002 & 290 & 7.39 & 298 \\
2003 & 357 & 1.04 & 358 \\
2004 & 441 & .563 & 442 \\
2005 & 406 & & 406 \\
\hline
\end{tabular}

Table 9d. Total Sales of Incumbent Exporters: Continuing Products Dropped

\begin{tabular}{|cccc|}
\hline \multicolumn{4}{c}{ (millions of US \$) } \\
& $\begin{array}{c}\text { Continuing } \\
\text { Products } \\
\text { Surviving 99-05 }\end{array}$ & $\begin{array}{c}\text { Continuing } \\
\text { Products } \\
\text { Dropped Before 05 }\end{array}$ & Total \\
\hline 1999 & 2180 & 327 & 2510 \\
2000 & 2230 & 250 & 2480 \\
2001 & 2060 & 205 & 2260 \\
2002 & 2070 & 180 & 2250 \\
2003 & 2100 & 61.5 & 2160 \\
2004 & 2230 & 27.5 & 2260 \\
2005 & 2160 & & 2160 \\
\hline
\end{tabular}

